\title{
PROFILE OF TRADITIONAL JAMU BUSINESS IN BENGKULU CITY
}

\author{
Agung TriSusilo'); Putri Suci Asriani2); Apri Andani2) \\ 1)Study Program of Agribusiness Magister Faculty of Agriculture, \\ University of Bengkulu \\ 2) Department of Agricultural Socio-Economics, Faculty of Agriculture, University of \\ Bengkulu \\ Email: ${ }^{1) a g u n g t r i s u s i l o . a t @ g m a i l . c o m ~}$
}

\begin{abstract}
How to Cite :
Trisusilo, A., P.S. Asriani, A. Andani, 2020. Profile of Traditional Jamu Business in Bengkulu City.Journal of Agri Socio-Economics and Business. 2 (1): 45-58. DOI:https://doi.org/10.31186/jaseb.1.2.45-58
\end{abstract}

\section{ARTICLE HISTORY \\ Received [29 May 2020] \\ Revised [03 June 2020] \\ Accepted [22 June 2020]}

\section{KEYWORDS}

Traditional Jamu,

revenue,

cost,

profit

This is an open access article under the $C C-B Y-S A$ license

\section{ABSTRACT}

This study aims to make the profile of the "traditional jamu" business in Bengkulu City this research was conducted by survey method and had done from August till December 2017. This research used descriptive analysis, $R / C$ ratio, and Return on Investment analysis. The owners stay in 7 subdistrict in Bengkulu City. Ratu Agung Sub-District be a place that most inhabited by the owners. The majority of owners are women and in the age group 45-54 years old. They have experience for 24, 23 years with educational level only to elementary school. At once, in the producess of producing also need of IDR 75.750,15 while the income IDR 189.000. $R / C$ ratio 2,49 and return on investment $149,5 \%$. The owners have positive perception and hight motivation with their business. So this business appropriate to do so.

\section{INTRODUCTION}

One method of treatment known in Indonesia is by mixing the plants into health drinks. Permenkes No. 0584 / MENKES / SK / VI / 1995 explained that 
Traditional Jamu is an ingredient or ingredients in the form of plant, animal, mineral, extract, or mixtures of these materials which are hereditary and applied by the norms prevailing in the society. One type of herbal medicine is traditional jamu. Herbal medicine is interpreted as a medicine that boat from the roots or leaves, and so on the ingredients of traditional jamu (Burhan \& Mustajib, 2010).

Traditional jamu is identical to the Javanese community. Even so at this time, herbal medicine has been known in various regions, both domestically and internationally. The traditional jamu business owners are generally Javanese people, especially Central Java. They expanded to other areas through transmigration programs and migrated independently with the main objective being to make a living. One of the cities that became their destination was Bengkulu City.

There are big potential in traditional jamu business. One of them is was the benefit of jamu to health. Now, the community is more like consume the products being made from natural materials and having the benefit for health. In addition, the traditional jamu can be comsumed by everyone, not limited to age and social class (Muslimin, et al, 2009)

Traditional jamu also has historical values and cultural values that can be sold. The traditional jamu resulting from Indonesia local culture. Althought the traditional jamu is identical with java culture, but in fact almost all regions in Indonesia has the method of treatment similar to tradisional jamu. Bengkulu Province is one of the many region who has methode of treatment. Murni et al (2012) states that the Serawai community in South Bengkulu District still use the herbs in the method of treatment. In other research, known that the Lembak Delapan community in Central Bengkulu are use 30 type of herbs to treat 49 kinds of a disease that infect the surrounding community (Yani, 2013).

The explanations above are reasons traditional jamu can may be able to stand up to the present time. The existence of traditional jamu in Bengkulu City shows that this business has excellent potential marketplace. If the traditional jamu is packed in interesting will be able to become a positive trend in the future. The owners made the traditional jamu as business commodity. They sell the traditional jamu with door to door. Though they have run the business decades, their living standard not increased significanly. Based on observations by Asriani et al (2014), known that the traditional business in the Bengkulu City done individually. As a result, their businesses not in accordance with the business management. The equipments are used very simple, not seen sanitation and higienity of production process. So that the quality and quantity of a product has been produced is still low.

The owners are trying to maintain this business despite they have limitations. They have to preserve the culture of the nations and made this business as their main source income. The average business owners have done this business for 25 years. Although in limitation they were able to survive very long time. This proved that business owners have motivation and business instinct strong. 
As a potential business unit, will be meaningless when are not managed well. The limitations are happens can be improved with a good business management. Business profile of traditional jamu in Bengkulu City need to be made because to introduce the traditional jamu business to the community and that the younger generation is more interested to developing this business. The business profile consists of characteristics of business owners, the production planning process to the analysis of traditional jamu businesses, the perception and motivation of the traditional jamu business owners.

\section{RESEARCH METHODS}

The basic method used in this study is the survey method. According to Daniel (2010), the survey method is a research method using critical observations or investigations to get good information on a particular problem in an area. This research was conducted in Bengkulu City from August to December 2017. Bengkulu City was chosen with the consideration that Bengkulu City became the center of the development of the traditional jamu business household industry in Bengkulu Province.

\section{Methods of Determining Respondents}

Respondents in this study were traditional jamu business owner in the Bengkulu City. The respondents were determined by the snowball sampling method. According to Patilima (2010), snowball sampling is a data collection activity from one respondent to another respondent that meets the criteria through indepth interviews and stops when there is no new information, replication, or repetition of variations in information and experiences a saturation point of information. Sugiyono (2017) explained that in the snowball sampling technique initially, the number of samples was small, then the sample was asked to choose friends to be sampled, so the longer the number of samples the more. There are 75 the traditional jamu business owners in Bengkulu City who were involved in this study.

\section{Method of Collecting Data}

According to Arikunto (2002), data collection techniques are a method used by researchers in collecting research data. Data and information needed in this study were obtained in two ways, namely field research and library research. 


\section{Data Analysis Method}

\section{Descriptive Analysis}

According to Setyosari (2010), descriptive research is research whose purpose is to explain or describe an event, condition, object associated with variables that can be explained using either numbers or words. Profile description of traditional jamu business is carried out by tracing the existence of traditional jamu business owners in Bengkulu City based on information obtained from business owners that have been found. The data collected is related to the location and market of the business, the production process, the characteristics of the business owners, perception and motivation of the business owners.

\section{Business Analysis}

Analysis methods used in the business analysis include revenue, profit, and business feasibility analysis consisting of R/C ratio, B/C ratio, and ROI. (Soekartawi, 2009).

\section{Revenue}

To calculate the amount of income in the Traditional Jamu Business in Bengkulu City the following formula is used:

$\mathrm{TR}=\mathrm{P} . \mathrm{Q}$

Notes:TR= Total Revenue (Rp); $\mathrm{P}=$ Price (Rp/cup); and Q= Quantitatif (cup)

\section{Profit}

To calculate the amount of profit $(\pi)$ in the Traditional Jamu Business in Bengkulu City the following formula is used:

$$
\pi=T R-T C
$$

\section{Revenue Cost Ratio (R/C)}

$\mathrm{R} / \mathrm{C}$ ratio is the ratio between income (revenue) with the total cost. By counting $\mathrm{R} / \mathrm{C}$ ratio can be determined the jamu tradisional business, whether profitable or not.

$$
R / C \text { ratio }=\frac{\text { Revenue }}{\text { Cost }}
$$

Notes: $\mathrm{R} / \mathrm{C}$ ratio $>1$, profitable; $\mathrm{R} / \mathrm{C}$ ratio $=1$, Break Even Point; and $\mathrm{R} / \mathrm{C}$ ratio $<1$, unprofitable

\section{Return on Investmen (ROI)}

$\mathrm{ROI}$ is the ratio of net income for cost. The formula as follows: 


$$
R O I=\frac{\pi}{T C} \times 100 \%
$$

\section{Perception and Motivation of Traditional Jamu Business Owners}

To find out the perceptions and motivations of traditional jamu business owners for their business, a descriptive method is used. Description of answers is done by calculating the average value (mean) of respondent's answers to each question and as a whole. To categorize the average respondent's answers used class intervals that are sought with the following formula:

ClassInterval $=\frac{\text { HighestValue- LowestValue }}{\text { ClassNumber }}$

Table 1 Category for Perception and Motivation

\begin{tabular}{cl}
\hline Class Interval & Category \\
\hline $1 \leq$ mean $\leq 2,5$ & Negative/ low \\
\hline $2,6 \leq$ mean $\leq 4$ & Positive/ high \\
\hline
\end{tabular}

Sources: Data processed, 2017

\section{RESULTS AND DISCUSSION}

\section{Profile of Traditional Jamu Business in Bengkulu City}

To know more clearly about the business conditions of traditional jamu in Bengkulu City a business profile is prepared. The compiled business profile consists of the location and market of the business, the production process, the characteristics of the traditional jamu business owners, business analysis, as well as the perceptions and motivations of traditional jamu business owners. Traditional jamu business owners are scattered in all areas of Bengkulu City. Table 2 presents information about the location the residence of traditional jamu business owners in Bengkulu City by the district.

Three districts with the highest number of traditional jamu business owners are Ratu Agung District, Singaran Pati, and Ratu Samban. All three have the same regional character that is close to the market. Living close to the market makes their access to raw materials quite easy. Because their raw material supply system is still very simple, they often have to go to the market to buy fresh ingredients, such as jugs and so on. Also, living near the market makes production costs incurred smaller because it minimizes transportation costs. This condition is in line with the theory put forward by August Losch. According to Losch (1954) in Santoso, et al (2012) the further away from the market, consumers are reluctant to buy because of the high cost of transportation to the point of sale. So producers must choose an industrial location that is close enough to the consumer to obtain 
maximum profit. In other words, Losch suggested that the location of the industry should be placed in the market or near the market.

Table 2 The Residence of Traditional Jamu Business Owners in Bengkulu City

\begin{tabular}{lcc}
\hline \multicolumn{1}{c}{ Subdistrict } & The number of people (person) & Percentage (\%) \\
\hline Ratu Agung & 24 & 32.00 \\
Muara Bangka Hulu & 5 & 6.67 \\
Gading Cempaka & 1 & 1.33 \\
Singaran Pati & 19 & 25.33 \\
Teluk Segara & 9 & 12.00 \\
Ratu Samban & 11 & 14.67 \\
Selebar & 6 & 8.00 \\
\hline \multicolumn{1}{c}{ Amount } & 75 & 100.00 \\
\hline
\end{tabular}

Sources: Data processed, (2017)

The traditional jamu market in Bengkulu City is still very broad. There are still locations that have not been touched by traditional jamu businesses. Therefore, sometimes one business owners has more than one selling location. In addition to expanding the market, this is also done to anticipate that consumers of traditional jamu do not get bored consuming traditional jamu every day. Some of the business owners sell their products to other regions, such as Seluma and Central Bengkulu District.

\section{Production Process of Traditional Jamu}

Traditional jamu business owners in Bengkulu City are producing some kinds of jamu every day. Four kinds of jamu must be produced by them, namely beras kencur, kunyit asem, pahitan, and wedang jahe. They produce the same product, but they have a different composition. They rely on instinct in producing traditional jamu. The production process of traditional jamu in Bengkulu City described in Figures 1, 2, 3, and 4.

\section{Beras Kencur}

The main ingredients to making beras kencur are rice and Kaempferia galanga. But it also needs a additives are Parkia timoriana, Illicium verum, Foeniculum vulgare, Amomum compactum, and Cinnamomum verum. Steps to make beras kencur, are: 1) roast and mash the additives; 2 ) mash the main ingredient; 3 ) add an additives into the main ingredients: 4) mash and mix it; 5) extract it with some water; 6) Boil the extract and add some sugar and salt; 7) filter out the extract. For more detail is presented in figure 1. 


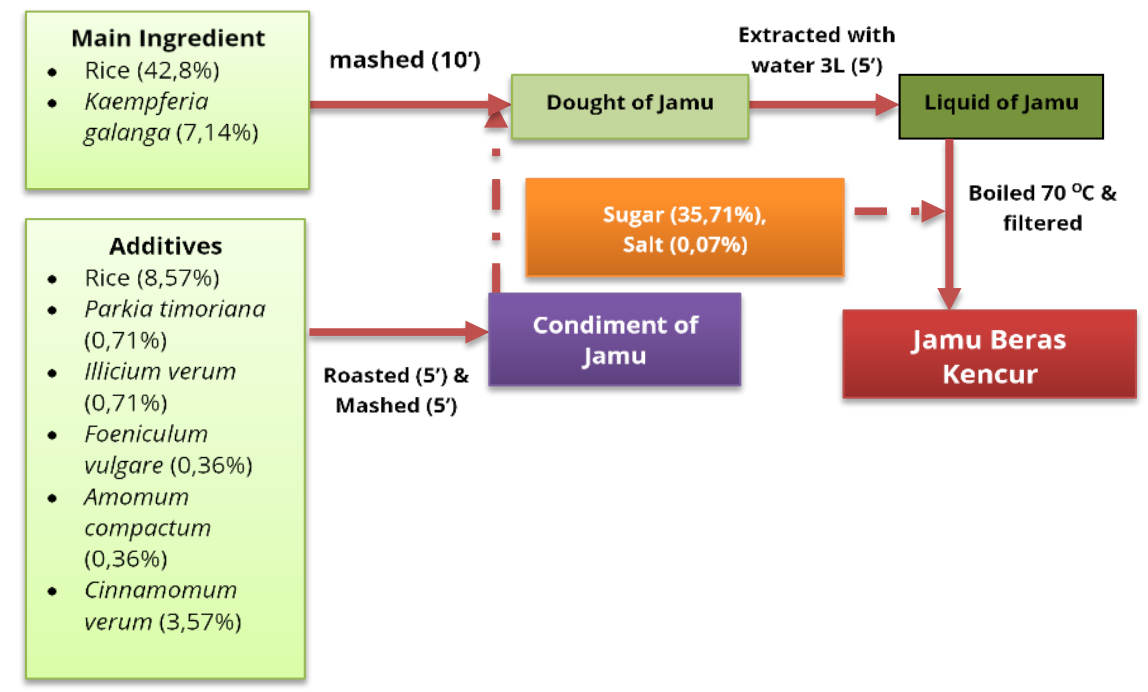

Figure 1

Production Process of Beras Kencur

\section{Pahitan}

The main ingredient to making pahitan is Andrographis paniculata. Steps to make pahitan, are: 1) mash the main ingredients; 2) extract it with some water; 3) Boil the extract; 4) filter out the extract. For more detail is presented in figure 2.

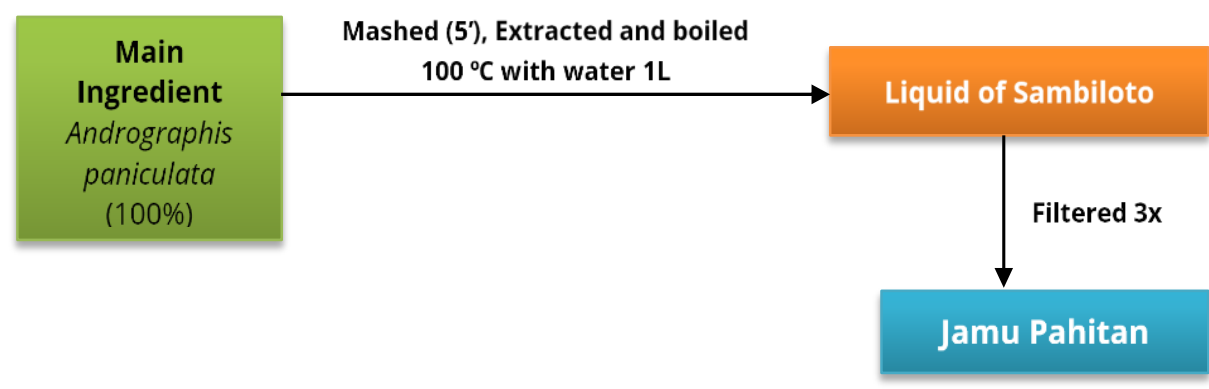

Figure 2

Production process of Pahitan

\section{Kunyit Asem}


The main ingredients to making kunyit asem are Curcuma longa and Betel. Steps to make kunyit asem, are: 1) mash the main ingredients; 2) extract it with some water; 3) Boil it and add tamarind, some sugar and salt; 4) filter out the extract. For more detail is presented in figure 3.

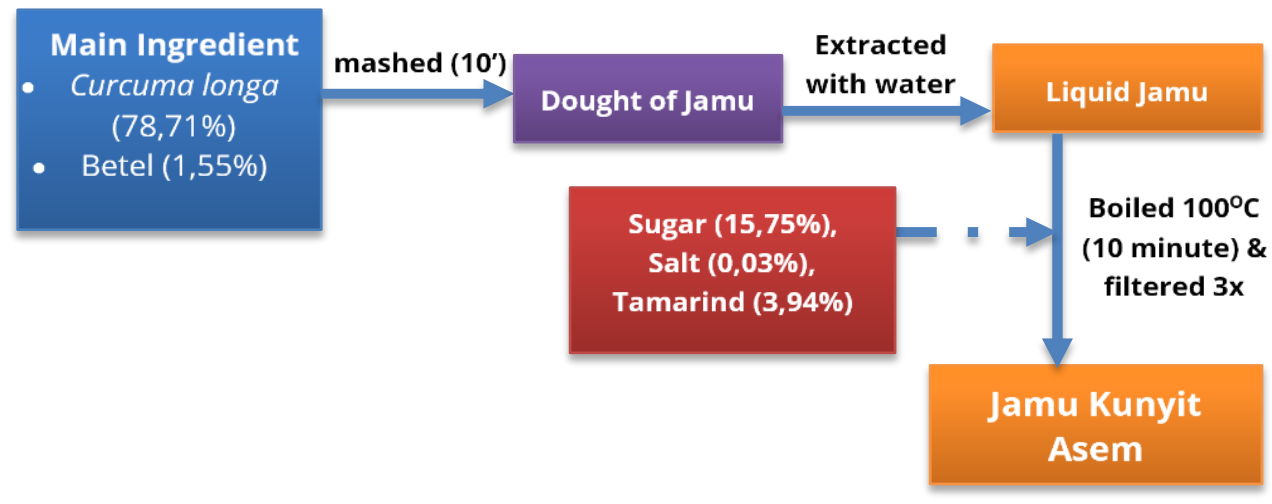

Figure 3

Production Process of Kunyit Asem

\section{Wedang Jahe}

The main ingredients to making wedang jahe are Zingiber officinale, Syzyygium polyantum, Citrus hystrix leaves, and pandanus. Steps to make wedang jahe, are: 1) mash the main ingredients; 2) extract it with some water; 3) Boil it and add palm sugar, some cane sugar and salt; 4) filter out the extract. For more detail is presented in figure 4.

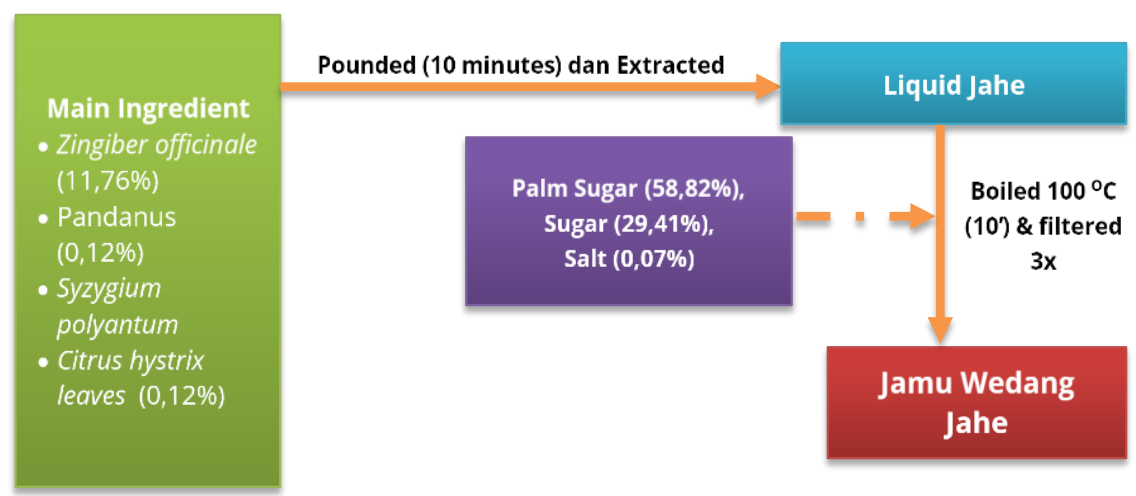

Figure 2

Production process of Wedang Jahe 


\section{Characteristic of Traditional Jamu Entrepreneurs}

The majority of traditional jamu business owners are women. But along with the development of the times, this profession began to be glimpsed by men as an alternative to their business. There are 75 the traditional jamu business owners in Bengkulu City, three of them are mens. Two of the three business owners have a wife as the owners. They see this business as a suitable source of family income. Next, they modified their marketing methods to make them fit. Currently, they sell traditional jamu by riding a motorcycle. With this method, they can reach consumers of traditional jamu to the nearest district border.

Kumbadewi, et al (2016) stated that age is one of the factors that influence a person's work productivity. According to Labor of Law No. 13 of 2003, the labor force is those who are in the age range of 15 - 64 years. Although in some professions the age does not prevent someone from continuing to work. One of them is the profession as a trader. The age average of traditional jamu business owners is 46,31 years old. The majority of them are at the age group $45-54$ years old. The regeneration in the business is very difficult. Only a few young interested to involved in this business. If this condition continues, the culture of drinking traditional jamu may disappear along with the retirement of old traditional jamu business owners.

The majority of the education level of traditional jamu business owners in Bengkulu City is still low, just in 5.18 years. It is the same with they are not having graduated from Elementary School. This condition occurs because their parents cannot actually afford to their school. Desptefully, at the time their parents assume that the womens do not need highly educated. Althought highly educated, they are just going to work in the home. Therefore, they are preferred to be directed to work in the home and assist the economic of family by being a traders or farm laborers. Even though their education level is in a low category, they can manage their business well, so that it can be used as their main source of income. According to Nainggolan (2016), the level of education of UMKM owners does not affect the income earned.

Traditional jamu is identical with Javanese. Therefore majority of the traditional jamu business owners derived from Java Island. Majority of them came from Solo and Sukoharjo, Central Java. There are the owners who come froma West Kalimantan and Bengkulu Province. This happens because they were married by the javanese. Besides from the family, ability to make the traditional jamu they learned of their senior.

Traditional jamu business owners in Bengkulu City have experienced during 24,23 years. As many as $69,33 \%$ of them have trade for 19 - 36 years. This condition shows that this business has been accepted by the community and has a market in Bengkulu City. The consumers would recommend their families to drink the traditional jamu. If they were satisfied with services provided one of business owners, so they will always consume the traditional jamu from its owners. 


\section{Business Analysis of Traditional Jamu in Bengkulu City}

Production cost consisting of a variable and fixed costs. In a business needed raw and additional ingredient, a production and marketing equipment. The variable cost consist of labor, raw and additive material cost. It will depreciation of equipment cost is fixed cost. Detail the cost of required in traditional jamu production process is presented in Tabel 3.

Table 3 Production Cost of Traditional Jamu per Process Production

\begin{tabular}{|c|c|c|}
\hline No & Component Cost & Amount (Rp) \\
\hline \multirow[t]{5}{*}{1} & Variabel Cost & \\
\hline & a. Raw Material & $38,984.67$ \\
\hline & b. Additive Material & $3,264.92$ \\
\hline & c. Labour & 31.250 .00 \\
\hline & Sub-total & $73,499.59$ \\
\hline \multirow[t]{4}{*}{2} & Fix Cost & \\
\hline & a. Depreciation Cost & $2,250.56$ \\
\hline & Sub-total & $2,250.56$ \\
\hline & Total & $75,750.15$ \\
\hline
\end{tabular}

Source: Processed data, (2017)

The raw materials used are rice, galingale, saffron, ginger, brown sugar, sugar, betel nut, betel, Curcuma, Quercus infectoria, and cayenne pepper. The additional materials used are rice, cinnamon, cardamom, fennel, and Parkia timoriana. The owners need IDR 42,249,59/ process production to buy raw and additive material.

Labor is one important factor in a traditional jamu business. Labor is using labor in the family. In a moment for as any process affecting the production it often takes some time 2 hours to make a jamu and 3 hours to market it as such. Labor costs are incurred in the time as much as IDR 31.250/process production.

During the production process, the owners used equipment of production. The equipment of production used are: a mortar, pestle, millstone, blender, grater, pot, basin, sieve, knife, and stove. Besides a equipment of production, the owners also require equipment to marketing. There are two kinds of marketing methods used by owners, namely on foot and a vehicle as a bicycle or motorcycle. To owner who on foot, they used a basket that carries on their backs as a bring bottle of jamu. They who using vehicles, and they tapped in a wooden box that is laid at the back of their vehicles. Marketing tools used in traditional jamu business are basket, bottles, glasses, funnel, bucket, spoon, napkin, scissors, and cloth pickaback. Every equipment used, the owners had to pay the depreciation cost. This business needed depreciation cost of IDR 2,250.56/ process production.

The traditional jamu business bring 7 to 13 bottles jamu with volume 1 liter.. Each bottle contains 7 to 10 cups, with range price per cup between IDR 2,000.00 to IDR 4,000.00 depending on the consumer. Table 4 provides information on 
business income traditional jamu business owners in Bengkulu City per production process.

Table 4 Business Income Traditional Jamu Entrepreneurs

\begin{tabular}{|c|c|c|}
\hline NO & Description & Amount (Rp) \\
\hline 1. & Total Revenue & $189,000.00$ \\
\hline 2. & Total Cost & $75,750.15$ \\
\hline & Profit & $113,249.85$ \\
\hline
\end{tabular}

Source: Processed data, 2017

Once the production process, they would make a profit of IDR 113,249,85. The profit counts large enough if compared against a time that is poured out, namely 5 hours a day. Begins with a willing any process affecting the production, marketing is done that is when they back home. If compared between income and time, so the profit gained by this business IDR 26,648.37/ hour.

\section{R/C Ratio}

Based on a comparison the profit with a total cost obtained an R/C ratio of 2 ,49. The outcome indicates that each addition of IDR 100 the cost, so will be produced income of IDR 249. So it will be concluded that Traditional Jamu Business profitable to do.

\section{Return on Investment (ROI)}

$\mathrm{ROI}$ is profit ratios intended to measure the aptitude in reversion company business capital used on the company operational. Based on ratios profit and capital obtained ROI of $149.5 \%$. The result indicates that the company in payback capital as a good category. It is because of any additional capital IDR 100 will be obtained a profit of IDR 149.5.

\section{Perception}

Kotler (2002) states that perception is the process of how a person selects, organizes, and interprets information inputs to create a meaningful picture of health. The perception of Traditional Jamu Business owners in the evaluation of Traditional Jamu Business owners against the businesses they live in. They were asked to rate the marketing mix component of their business. On a scale of numbers 1-4, the average assessment of the level of business owners' perception of their businesses is 3.26. This condition shows that Traditional Jamu Business owners in Bengkulu City have a positive view of their business marketing mix.

In general, they have a positive view of their business marketing mix. But there are some statements related to product attributes that are considered not good. Some of these points include product legality at the relevant agencies and product availability at certain outlets. Regarding these two points, they cannot do 
more. The limited knowledge and complexity of the bureaucracy is a barrier for them to take care of the licensing that is needed in their business.

\section{Motivation}

Zirmansyah (2013) states that motivation is a physiological and psychological condition found in humans that regulates actions in certain ways. Motivation is also interpreted as a person's hope to get satisfaction in completing a difficult and challenging task. According to Nawawi (2006), work motivation is a condition that drives or becomes the cause of someone doing an action.

On a scale of numbers $1-4$, the average rating of the motivation level of Traditional Jamu entrepreneurs is 3.44. This condition shows that the motivation level of Traditional Jamu Business owners in Bengkulu City is high. They are very open with constructive criticism and suggestions from various parties. Although they have experience in making Traditional Jamu, it is possible that what they have done so far has not been right.

The tradisional jamu business owners do not mind cooking utensil used. They consider all of cooking utensil is the same. They used aluminium utensil for cooking jamu. This utensil is not recommended for cooking jamu by the Ministry of Health and they recommended to use the enamel or stenles steel cooking utensil. They receive the recommendations are with pleasure. They replace the utensil based on recommendations gradully, although the price is more expensive. This proved that they have high motivation to keep learning and improve the quality of their products and services.

\section{CONCLUSIONS AND RECOMENDATIONS}

\section{Conclusions}

The Traditional Jamu entrepreneurs spread in seven subdistricts in Bengkulu City and Ratu Agung become a most inhabited by Traditional Jamu entrepreneurs. Traditional Jamu entrepreneurs the majority were from the Central Java Province. The majority of them are women aged 45 to 54 years old. They have experience for 24.23 years and educated only elementary school graduates.

The cost of production is needed as much as IDR 75.750,15. The income obtained will enable IDR 189.000. R/C ratio resulting as much as 2,49 and ROI $149,5 \%$. So this business appropriate to do so. Traditional Jamu Business practitioners positively perceive their business marketing mix. Furthermore, they also have high motivation in carrying out Traditional Jamu Business. 


\section{Recommendations}

To young entrepreneurs who want business opportunities, Traditional Jamu Business could become alternate. This business profitable, the market still wide open so have a low risk of competition.

\section{REFERENCES}

Arikunto, S. 2002. Metode Penelitian Suatu Pendekatan Proposal. Jakarta. Rineka Cipta Asriani, Putri Suci, Bonodikun, dan E Yuliarti. 2014. Laporan Akhir PPM Penerapan IPTEK “Pemberdayaan Perempuan Pengrajin Jamu Gendong Melalui Penerapan Teknologi Diversifikasi Produk Olahan. Jurusan Sosial Ekonomi Pertanian. Universitas Bengkulu (Tidak Dipublikasi)

Burhan, dan Mustajib. 2010. Magang Kewirausahaan pada Industri Kecil Jamu Tradisional Ramuan Madura. Prosiding Seminar Nasional Manajemen Teknologi XI. Prodi MMT-ITS

Daniel. H. 2010. Metode Penelitian Sosial Ekonomi. PT. Bumi Aksara. Jakarta

Kotler, P. 2002. Manajemen Pemasaran. Edisi Milenium. Jakarta. Prehallindo. 818 pp

Kumbadewi, Luh Sri, I W Suwendra, G P A J Susila. 2016. Pengaruh Umur, Pengalaman Kerja, Upah, Teknologi dan Lingkungan Kerja terhadap Produktivitas Karyawan. E-Journal Bisma Universitas Pendidikan Ganesha Jurusan Manajemen. 4: 11-21

Murni, S. Angria, P. Prawito, dan S. Widiono. 2012. Eksistensi Pemanfaatan Tanaman Obat Tradisional (TOT) Suku Serawai di Era Medikalisasi Kehidupan. Naturalis Jurnal Penelitian Pengolahan Sumber Daya Alam dan Lingkungan. I(3): 225-236.

Muslimin, L., B. Wicaksena, B. Setiyawan, N. A. Subekti, H. Sukesi, H. Surachman, A. Santorio, I. Karim, S. Hartini, A. Yulianti, I. C. Setepu, dan Khaidir. 2009. Kajian Potensi Pengembangan Pasar Jamu. Pusat Penelitian dan Pengembangan Perdagangan Dalam Negeri. Badan Penelitian dan Pengembangan Perdagangan. Kementerian Perdangan. 215 pp.

Nafarin, M. 2007. Penganggaran Perusahaan. Edisi Ketiga. Jakarta: Salemba

Nainggolan, Romauli. 2016. Gender, Tingkat Pendidikan dan Lama Usaha sebagai Determinan Penghasilan UMKM Kota Surabaya. Jurnal Kinerja 20(1): 1-12

Nawawi, H. 2006. Manajemen Sumber Daya Manusia. Yogyakarta: Gadjah Mada University Press. 437 pages

Patilima, Hamid. 2010. Metode Penelitian Kualitatif. Malang: UMM Press. 
Republik Indonesia. 1995. Keputusan Menteri Kesehatan Nomor 0584/Menkes/SK/VI/1995 tentang Sentra Pengembangan dan Penerapan Pengobatan Tradisional. Sekretariat Negara. Jakarta

Republik Indonesia. 2003. Undang-undang Republik Indonesia Nomor 13 Tahun 2003 tentang Ketenagakerjaan. Sekretariat Negara. Jakarta

Santoso, Eko Budi. E. Umilia. B. U. Aulia. 2012. Diktat Analisis Lokasi dan Keruangan. Surabaya. Prodi Perencanaan Wilayah dan Kota Fakultas Teknik Sipil dan Perencanaan ITS

Setyosari, Punaji. 2010. Metode Penelitian dan Pengembangan. Jakarta. Kencana Soekartawi. 2009. Agribisnis. Teori dan Aplikasinya. Rajawali Pers. Jakarta

Sugiyono. 2017. Metode Penelitian Kuantitatif, Kualitatif, dan $R$ \& D. Bandung. Alfabeta

Yani, A. P. 2013. Kearifan Lokal Penggunaan Tumbuhan Obat oleh Suku Lembak Delapan di Kabupaten Bengkulu Tengah Bengkulu. Prodising Semirata FMIPA. UNILA. Lampung

Zirmansyah. 2013. Persepsi dan Motivasi Mahasiswa Universitas Al Azhar Indonesia terhadap Pembelajaran Mata Kuliah Universitas. Jurnal Al-Azhar Indonesia Seri Humaniora 2(2): 126-141, September 2013. 